\title{
САМОВРЯДУВАННЯ В СИСТЕМІ ОХОРОНИ ЗДОРОВ'Я УКРАЇНИ
}

\author{
${ }^{1}$ Тернопільський національний медичний університет \\ імені І. Я. Горбачевського МОЗ України, м. Тернопіль, Україна \\ ${ }^{2}$ Українська академія друкарства, м. Львів, Україна
}

\begin{abstract}
Мета: проаналізувати засади самоврядування в системі охорони здоров'я для можливостей його імплементації в Україні.

Матеріали і методи. Використовуючи методи системного аналізу, показано стан функціонування самоврядних професійних організацій в охороні здоров'я та можливості його запровадження в Україні.

Результати. Показано причини появи необхідності запровадження лікарського самоврядування в ряді європейських країн. Розглянуто позитивні та проблемні сторони лікарського самоврядування, шляхи його запровадження в Україні.

У більшості розвинених країн світу працюють самоврядні організації в системі медичної допомоги, і про те, що вони $€$ гарантом високої якості медичної допомоги, говорять їх управлінські органи. Вони здійснюють це право і мають здатність реально регламентувати значну частину державних справ та управляти діяльністю в системі медичної допомоги, діючи в рамках закону, під свою відповідальність і в інтересах місцевого населення.

У лікарській практиці багатьох країн світу існує певна дилема: з одного боку, це клінічні протоколи, яким лікар у більшості випадків має слідувати, а з іншого - лікарське самоврядування, яке допускає свободу його дій.

В Україні запровадження в медицині принципів самоврядування полягало у створенні громадських організацій на кшталт Лікарського товариства, Асоціації лікарів тощо. Але слабкою їх стороною було те, що вони мали право лише дорадчого голосу.

Висновки. Виходячи із аналізу діяльності органів лікарського самоврядування та реалій української медичної спільноти, можемо зробити висновок про назрівання необхідності запровадження профресійного медичного самоврядування в Україні. Імплементація медичного самоврядування в Україні потребує адекватної нормативної бази, узгодження положень про самоврядування з існуючою нормативною базою.
\end{abstract}

КЛЮЧОВІ СЛОВА: самоврядування; система охорони здоров'я; медична допомога.

Вже декілька років говориться про те, що у більшості розвинених країн світу працюють самоврядні організації в системі медичної допомоги і, нібито саме вони є гарантом високої якості медичної допомоги. Ці твердження вживаються як аргументи для обґрунтування необхідності запровадження такої ж системи в Україні.

Мета роботи: проаналізувати засади самоврядування в системі охорони здоров'я для можливостей його імплементації в Україні.

Матеріали і методи. Використовуючи методи системного аналізу, показано стан функціонування самоврядних професійних організацій в охороні здоров'я та можливості його запровадження в Україні.

Результати дослідження та їх обговорення. Єдиного наукового визначення поняття «самоврядування» немає, хоч у літературі $€$ різні підходи до цього поняття. Загальновідомим є те, що самоврядування у будь-якій системі передбачає насамперед самостійне фрункціонування, що зумовлює самостійне фрінансування та самоорганізацію - за принципом «Хто платить - той замовляє музику».

Якщо взяти за аналогію визначення Європейською хартією місцевого самоврядування, то вона наголошує, що це право і реальна здатність цих органів регламентувати значну частину дер- жавних справ і управляти діяльністю в системі медичної допомоги, діючи в рамках закону, під свою відповідальність і в інтересах місцевого населення.

Тридцять п'ять років тому, в 1987 р. у Іспанії 39-ю Всесвітньою медичною асамблеєю була прийнята Мадридська декларація відносно професійної автономії лікарів і самоуправління. Основна її мета полягала в тому, щоб дати можливість лікарям вільно реалізовувати власні профресійні рішення при наданні медичної допомоги пацієнтам. Водночас передбачалась і відповідальність за контроль над професійною поведінкою та діяльністю окремих лікарів. Таким чином, практично визнавалась та задекларовувалась профресія лікаря як вільна професія 3 усіма наслідками [1].

Разом із тим, ніхто не скидає з рахунків тисячолітньої традиції clinical practice guideline - клінічної практичної настанови, яка мала провідну ідею визначення критеріїв діагностики, полегшення прийняття рішень, ведення та лікування пацієнтів. Власне кажучи, це був прототип нинішніх стандартів лікування. На сьогодні клінічний протокол - це інструкція для лікаря, документ, в якому зібрані настанови для лікування конкретної хвороби, щоб уникати неефективних та помилкових рішень і обирати найефектив- 
ніше втручання щодо пацієнта. Тобто лікар не мусить (і не має права) щоразу «винаходити велосипед» - $€$ перевірені способи діагностики і лікування, які довели свою ефективність. За сучасних умов лікар зобов'язаний знати медичні настанови зі своєї професії. У більшості країн, де працює лікарське самоврядування, саме лікар може вирішувати, чи потрібно дотримуватись рекомендацій для лікування конкретного пацієнта чи він приймає власне рішення, за яке нестиме відповідальність. Практика показує, що у більшості випадків лікарі дотримуються рекомендацій клінічних протоколів - так легше, простіше і безпечніше у разі претензій з боку пацієнтів.

Таким чином, у лікарській практиці багатьох країн світу існує певна дилема: з одного боку, це клінічні протоколи, яких лікар у більшості випадків має дотримуватись, а 3 іншого - лікарське самоврядування, яке допускає свободу його дій [5].

Що ж у цьому плані відбувається в Україні? Останніми роками реформа системи охорони здоров'я передбачає певні кардинальні зміни як в організації самої системи медичної допомоги, так і в зростанні вимог до її матеріального забезпечення, запроваджує інновації в клінічних протоколах, ініціює все більше фрорм контролю лікаря та зростання вимог до його кваліфікації, що, безумовно, працює на користь пацієнта.

18 серпня 2021 р. Президент України Володимир Зеленський підписав указ № 369/2021, який вводить у дію рішення Ради національної безпеки і оборони «Про стан національної системи охорони здоров'я та невідкладні заходи щодо забезпечення громадян України медичною допомогою», який був прийнятий на засіданні РНБО 30 липня [3]. Щодо проблемної ситуації 3 медичними кадрами у документі зазначається, що «кадрове забезпечення системи охорони здоров'я характеризується відсутністю послідовної стратегії забезпечення галузі спеціалістами необхідного профрілю, що спричиняє відтік із галузі високопрофесійних фрахівців та молодих спеціалістів». Однак, далі визнання проблеми, пропозицій щодо її вирішення у документі немає. Така ситуація 3 позицій держави деякою мірою зрозуміла. Державу цікавить ефективний результат - здоров'я нації 3 найменшим вкладанням коштів, тому і пропонується посилена система контролю, оптимізація вторинного та третинного рівнів медичної допомоги тощо. Не піднімаються й інші питання оптимізації роботи лікарів, окрім посиленого контролю за їх діяльністю. Така позиція явно аргументує необхідність вирішення даних питань системою лікарського самоврядування, якої наразі немає, як і стратегічного бачення її створення.

В Україні було кілька спроб запровадити в медицині принципи самоврядування. В основному це зводилось до створення громадських організацій на кшталт Лікарського товариства, Асоціації лікарів тощо. Метою цих організацій в основному було запровадження методів участі медичної громадськості у вирішенні проблемних питань в медицині та охороні здоров'я на державному рівні. Але слабкою їх стороною було те, що вони мали право лише дорадчого голосу. Законодавчих важелів впливу на виконання їх рішень такі організації не мали і не мають апріорі в силу свого статусу. Тому і виникла необхідність створення самоврядної медичної організації на принципово нових засадах. I таких проектів в Україні було вже близько десятка. Частина з них подавалась на розгляд до Верховної Ради України, але була відхилена.

27 січня у Верховній Раді України народні депутати розглядали останній проект Закону № 2445-д «Про самоврядування медичних профресій в Україні» та альтернативні до нього проекти за №№ 2445-1, 2445-2, 2445-3 і 2445-д. У результаті розгляду законопроект № 2445-Д теж було відхилено [4].

Основні причини неприйняття цих проектів це неузгодженість певних позицій. Перша з таких невизначеностей - це обов'язкова чи добровільна участь в організації. У країнах Європи спостерігають обидва варіанти. А від цього залежить схема фрінансування організації. У даному законопроекті $є$ два варіанти - в одному випадку йдеться про внески членів самоврядування, а в іншому - пропонується запровадити в Україні професійне самоврядування медичних професій як особливий вид професійного самоврядування, що буде гарантуватися та забезпечуватися державою. Також виникне питання чи затвердження власних актів та ухвалення рішень, обов'язкових для виконання особами, на яких поширюється профресійне самоврядування (етичні кодекси, правила та стандарти професійної діяльності тощо), притягнення осіб, на яких поширюється профресійне самоврядування, до дисциплінарної (профресійної) відповідальності буде стосуватися всіх медичних працівників або лише членів самоврядування.

Саме визначення в законопроекті професійного самоврядування, як «особливого виду професійного самоврядування, що буде гарантуватися та забезпечуватися державою, і дасть кожному представнику медичних професій право управляти діяльністю професії, самостійно виконувати завдання та здійснювати повноваження», містить заперечення заперечень.

Виникає ряд питань до пункту про наділення органів професійного самоврядування повноваженнями щодо допуску до професійної діяльності в сорері охорони здоров'я (надання права на здійснення медичної діяльності), а також щодо тимчасового призупинення та припинення такого права. На сьогодні це функції виключно Міністерства охорони здоров'я України з усіма випливаючими позиціями чинного законодавства про ліцензування видів господарської діяльності [2].

На жаль, не мають ніякої аргументації прикінцеві положення про те, що впровадження професійного самоврядування сприятиме тому, що більше медичних та фрармацевтичних працівників побажають залишитися в Україні далі працювати 
і якість медицини та орієнтованість на пацієнта покращиться, рівень медицини почне зростати.

Попри ствердження, що у проекті закону відсутні правила і процедури, які можуть містити ризики вчинення корупційних правопорушень, все-таки вони будуть, якщо реалізується позиція видання дозволу на право професійної діяльності та її припинення.

Також не обґрунтовані прогнози соціальноекономічних та інших наслідків прийняття законопроекту, зокрема щодо невизначених джерел фрінансування, які дозволять запровадити і забезпечити постійний професійний розвиток медичних фрахівців та медицини в країні.

\section{Висновки}

Виходячи із аналізу діяльності органів лікарського самоврядування та реалій української медичної спільноти, можемо зробити висновок про назрівання необхідності запровадження професійного медичного самоврядування в Україні.

Імплементація медичного самоврядування в Україні потребує адекватної нормативної бази, узгодження положень про самоврядування 3 існуючою нормативною базою.

Перспективи подальших досліджень полягають у визначенні відповідності позицій професійного медичного самоврядування 3 реаліями існуючого законодавства та потребами практичної медичної допомоги і системи охорони здоров'я.

\section{Список літератури}

1. Мадридська декларація відносно професіональної автономії лікарів і самоуправління, прийнята 39-ю Всесвітньою медичною асамблеєю (Мадрид, Іспанія, 1987 р.) [Електронний ресурс]. - Режим доступу : https://med.sumdu.edu.ua/ images/content/doctors/Deontology/Madrid_1987.pdf.

2. Про ліцензування видів господарської діяльності : Закон України від 02.03.2015 р. № 222-VIII [Електронний ресурс] // Відомості Верховної Ради України. - 2015. - № 23. - Ст. 158. - Режим доступу : https://zakon.rada.gov.ua/ laws/show/222-19\#Text.

3. Про рішення Ради національної безпеки і оборони України від 30 липня 2021 р. «Про стан національної системи охорони здоров'я та невідкладні заходи щодо забезпечення громадян України медичною допомогою»: Указ Президента України від 18.08.2021 р. № 369/2021 [Електронний ресурс]. - Режим доступу : https://www.president. gov.ua/documents/3692021-39713.

4. Про самоврядування медичних професій в Україні : Проект Закону України від 03.07.2020 р. № 2445-д [Електронний ресурс]. - Режим доступу : http://w1.c1.rada.gov.ua/pls/zweb2/webproc4_1?pf3511=69359.

5. Устінов О. В. Лікарське самоврядування: міжнародний досвід таперспектива впровадження в Україні [Електронний ресурс] / О. В. Устінов. - Режим доступу : https://www.umj.com.ua/article/68521/likarske-samovryaduvannyamizhnarodnij-dosvid-ta-perspektiva-vprovadzhennya-v-ukraini.

\section{References}

1. (1987). Madrydska deklaratsiya vidnosno profesionalnoyi avtonomiyi likariv i samoupravlinnya [Madrid Declaration on the Professional Autonomy of Physicians and Self-Government]. Pryynyata 39-yu vsesvitnoyu medychnoyu asambleyeyu, Madryd, Ispaniya. Retrieved from: https://med.sumdu.edu.ua/images/content/doctors/Deontology/Madrid_1987.pdf [in Ukrainian].

2. (2015). Zakon Ukrayiny «Pro litsenzuvannya vydiv hospodarskoyi diyalnosti» [Law of Ukraine «On licensing of economic activities»]. Vidomosti Verkhovnoyi Rady - Information of the Verkhovna Rada, 23, 158 [in Ukrainian].

3. (2021). Ukaz Prezydenta Ukrayiny №369/2021 Pro rishennya Rady natsionalnoyi bezpeky i oborony Ukrayiny vid 30 lypnya 2021 roku «Pro stan natsionalnoyi systemy okhorony zdorovya ta nevidkladni zakhody shchodo zabezpechennya hromadyan Ukrayiny medychnoyu dopomohoyu» [Decree of the President of Ukraine No. 369 / 2021 On the decision of the National Security and Defense Council of Ukraine of July 30, 2021 «On the state of the national health care system and urgent measures to provide citizens of Ukraine with medical care»]. Retrieved from: https://www.president.gov.ua/ documents/3692021-39713 [in Ukrainian].

4. (2020). Proekt Zakonu pro samovryaduvannya medychnykh profesiy v Ukrayini № 2445-d vid 03.07.2020 [Draft Law on Self-Government of Medical Professions in Ukraine No. 2445-d dated 03.07.2020]. rada.gov.ua. Retrieved from: http:// w1.c1.rada.gov.ua/pls/zweb2/webproc4_1?pf3511=69359 [in Ukrainian].

5. Ustinov, O.V. (2021). Likarske samovryaduvannya: mizhnarodnyy dosvid ta perspektyva vprovadzhennya v Ukrayini [Medical self-government: international experience and prospects for implementation in Ukraine]. Ukrayinskyy medychnyy chasopys - Ukrainian Medical Journal, 44(144), VII/VIII Retrieved from: https://www.umj.com.ua/article/68521/likarskesamovryaduvannya-mizhnarodnij-dosvid-ta-perspektiva-vprovadzhennya-v-ukraini [in Ukrainian].

\section{SELF-GOVERNMENT IN THE HEALTHCARE SYSTEM OF UKRAINE}

O. N. Lytvynova ${ }^{1}$, L. P. Zaporozhan ${ }^{1}$, K. Ye. Yuriyiv ${ }^{1}$, M. S. Fesh ${ }^{2}$

${ }_{1}$. Horbachevsky Ternopil National Medical University, Ternopil, Ukraine

Ukrainian Academy of Printing, Lviv, Ukraine

Purpose: to analyze the principles of self-government in the health care system for the possibilities of its implementation in Ukraine.

Materials and Methods. Using the methods of system analysis, the state of functioning of self-governing professional organizations in health care and the possibility of its introduction in Ukraine are shown. 
Results. The reasons for the necessary to introduce medical self-government in a number of European countries are shown. The positive and problematic aspects of medical self-government, ways of its introduction in Ukraine are considered.

In most developed countries, self-governing organizations operate in the health care system and their governing organisations say that they are the guarantor of high quality health care. Exercise this right and have the ability to actually regulate a significant part of public affairs and manage it, acting within the law, under their own responsibility and in the interests of the local population.

In the medical practice of many countries there is a dilemma: on the one hand there are clinical protocols, which the doctor in most cases must follow, and on the other there is medical self-government, which allows freedom of action.

In Ukraine, the introduction of the principles of self-government in medicine consisted in the creation of public organizations such as the Medical Society, the Association of Physicians, and so on. But their weakness was that they had only an advisory vote.

Conclusions. Based on the analysis of the activities of medical self-government and the realities of the Ukrainian medical community, we can conclude that there is the necessity for the introduction of professional medical self-government in Ukraine.

The implementation of medical self-government in Ukraine requires an adequate regulatory framework, harmonization of self-government regulations with the existing regulatory framework.

KEY WORDS: self-government; health care system; medical care.

Рукопис надійшов до редакції 20.08.2021 p.

\section{Відомості про авторів:}

Литвинова Ольга Несторівна - кандидат медичних наук, доцент кафедри громадського здоров'я та управління охороною здоров'я Тернопільського національного медичного університету імені І. Я. Горбачевського МОЗ України; тел.: +38(0352) 52-72-33.

Запорожан Лариса Петрівна - кандидат географрічних наук, доцент кафедри громадського здоров'я та управління охороною здоров'я Тернопільського національного медичного університету імені І. Я. Горбачевського МОЗ України; тел.: +38(0352) 52-72-33.

Юріїв Катерина Євгенівна - кандидат медичних наук, доцент кафредри патологічної фрізіології Тернопільського національного медичного університету імені І. Я. Горбачевського МОЗ України; тел.: +38(0352) 43-12-62. Феш Мирослава Степанівна - кандидат економічних наук, доцент кафедри підприємництва та маркетингу Української академії друкарства; тел.: +38(0322) 242-23-40. 